Izvorni znanstveni članak

DOI 10.54478/ers.30.43.1

\title{
RAZLIKE U ZADOVOLJSTVU TJELESNIM IZGLEDOM KOD STUDENTICA U RAZLIČITIM STADIJIMA PROMJENE PONAŠANJA POVEZANIH S TJELESNIM VJEŽBANJEM
}

\author{
Josipa Antekolović ${ }^{1}$ \\ ${ }^{1}$ Rudarsko-geološko-naftni fakultet Sveučilišta u Zagrebu
}

\begin{abstract}
Sažetak
Cilj ovog rada ispitati je razlike u percepciji tjelesnog izgleda studentica koje se, sukladno transteorijskom modelu, nalaze u različitim stadijima promjene ponašanja. Ispitat će se i razlike u zadovoljstvu vlastitim tjelesnim izgledom između aktivnih $i$ neaktivnih studentica. Korištena je skala za mjerenje procesa promjene utemeljena na transteorijskom modelu spremnosti na promjenu ponašanja povezanih s vježbanjem te skala percepcije tjelesnog izgleda slikovnim podražajima.U istraživanju je sudjelovalo 87 studentica Rudarsko-geološko-naftnog fakulteta

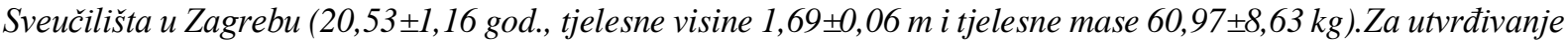
razlika u zadovoljstvu/nezadovoljstvu tjelesnim izgledom studentica po pojedinim stadijima transteorijskog modela korišten je Kruskal-Wallis test $(H(3)=2,44, p=0,49)$ a rezultati ukazuju da se studentice ovog uzorka ne razlikuju u zadovoljstvu/nezadovoljstvu tjelesnim izgledom po pojedinim stadijima transteorijskog modela. Neaktivne $i$ aktivne studentice ne razlikuju se niti u zadovoljstvu/nezadovoljstvu tjelesnim izgledom $(Z=0,40$, $p=0,69)$ niti prema stupnju uhranjenosti $(Z=-0,15, p=0,88)$.
\end{abstract}

Ključne riječi:nezadovoljstvo tjelesnim izgledom, predodžba tijela, studentice, transteorijski model

\section{Uvod}

Slika tijela, predodžba tijela ili body image mentalna je slika osobe o vlastitom tjelesnom izgledu, evaluaciji izgleda te utjecaja tih percepcija i stavova na ponašanje (Pokrajac-Bulian i Kandare, 1999). Osnova nezadovoljstva vlastitom slikom tijela razlika je između percipiranog i idealnog ja, neovisno radi li se o vlastitom unutrašnjem idealu ili idealu nametnutom od strane društva (Cleaves i sur., 2000). Jedan od poremećaja predodžbe o tijelu nezadovoljstvo je vlastitim tijelom. Nezadovoljstvo se može kretati od blagog nezadovoljstva specifičnim dijelovima tijela sve do ekstremnog omalovažavanja izgleda.Razina nezadovoljstva vlastitim tijelom ima utjecaj na samopoimanje, samopoštovanje i socijalno ponašanje ali i na razvoj poremećaja hranjenja (Pokrajac-Bulian i sur., 2005). Na percepciju tijela kao i na razvoj nezadovoljstva tjelesnim izgledom uvelike utječe kultura u kojoj živimo i nametnuti standardi o idealnom tjelesnom izgledu. Norme o idealnom tjelesnom izgledu prenose se putem medija, posebice oglasa modne i kozmetičke industrije ali $i$ putem različitih društvenih mreža.Sociokulturalna očekivanja o idealnom tjelesnom izgledu utječu na zabrinutost i nezadovoljstvo tjelesnim izgledom osoba oba spola. Kod žena nezadovoljstvo tijelom ide uvijek u smjeru gubitka tjelesne težine, dok se kod muškaraca očituje u gubljenju i dobivanju na tjelesnoj težini, posebice mišićnoj masi (Furnham i Calnan, 1998). U odnosu na muškarce, žene su zabrinutije i manje zadovoljne izgledom, sklonije precjenjivanju vlastite tjelesne težine, češće provode dijetu te iskazuju veću zabrinutost prilikom odabira i konzumacije namirnica (Pokrajac-Bulian i Kandare, 1999). Kod djevojaka adolescentne i rane odrasle dobi tjelesni ideal koji žele dostići puno je mršaviji od njihova trenutnoga izgleda(Wertheim i sur., 1999).

Svijest o tjelesnom izgledu može imati značajnu ulogu u utjecaju na mnoštvo zdravstvenih ponašanja poput zdrave prehrane (Baş i Kiziltan, 2007) ali i sudjelovanja u tjelesnim aktivnostima (Kruger i sur., 2008).Važan čimbenik koji indirektno utječe na povećanje kvalitete 
i zadovoljstva životom bavljenje je sportom i tjelesnim vježbanjem (Horga i Barić, 2018). Zadovoljstvo životom, kao širok pojam, podrazumijeva u svakom slučaju i zadovoljstvo tjelesnim izgledom. Prema Bungić i Barić (2009), autori većine radova s tom problematikom suglasni su u tome da su pomaci pod utjecajem tjelesnog vježbanja pozitivni, što se odnosi i na fizičku i na psihološku dobrobit pojedinca. Kako se smatra da zadovoljstvo tjelesnim izgledom poboljšava svakodnevno raspoloženje, jasno je da i ono, kao i tjelesna aktivnost, utječe na psihološku dobrobit. Za pretpostaviti je i da osoba zadovoljna vlastitim izgledom sebe smatra više atraktivnom od one koja je nezadovoljna pa samim time zadovoljstvo izgledom pozitivno utječe i na samopouzdanje. Poboljšanje predodžbe o vlastitom tijelu primjenom programa tjelovježbe učinkovito je kod oba spola (Campbell i Hausenblas, 2009) a osobe koje su tjelesno aktivne zadovoljnije su svojim tijelom od osoba koje žive sedentarnim načinom života (Bendixen i sur., 2007). Dosadašnje studije isticale su problem nedovoljne tjelesne aktivnosti i sklonosti rizičnom ponašanju. Ovaj problem posebno je vidljiv među studentskom populacijom (Allender i sur., 2008; Gyurcsik i sur., 2004; Keating i sur., 2005; L. H. McArthur i Raedeke, 2009; Nelson i sur., 2007). Usprkos evidentnim dokazima o koristi tjelesne aktivnosti mnogi pojedinci ne uspijevaju promijeniti svoje sedentarne navike i ne uspijevaju ustrajati u započetoj promjeni ponašanja. Promjene ponašanja povezanih s tjelesnim vježbanjem često se istražuju u okviru transteorijskog modela (Prochaska i Diclemente, 1983). Jedan je od glavnih doprinosa ovog modela što promjenu promatra kao kontinuirani proces i naglašava potrebu za procjenom individualne spremnosti za promjenu. Radi se o integrativnom modelu namjerne promjene ponašanja koji objašnjava i predviđa kako će i kada osoba promijeniti svoje ponašanje. Model predviđa da će se u osobe sistematski mijenjati spremnost za prihvaćanje zdravijeg ponašanja na temelju percepcije ravnoteže između prednosti i nedostataka koje donosi održavanje ponašanja te prednosti i nedostataka koje donosi promjena. U skladu s tim modelom, promjena ponašanja povezanih s vježbanjem uključuje kretanje kroz pet stadija: (1) predkontemplacija, (2) kontemplacija, (3) priprema, (4) akcija i (5) održavanje. U svojoj je osnovi ovaj model cirkularan i pretpostavlja da u procesu promjene osobe prolaze kroz iste stadije i nekoliko puta dok ne postignu održivu promjenu (D i Clemente, 1993).

U ovom će se radu ispitati razlike u percepciji tjelesnog izgleda studentica koje se, sukladno transteorijskom modelu, nalaze u različitim stadijima promjene ponašanja. Ispitat će se i razlike $\mathrm{u}$ zadovoljstvu vlastitim tjelesnim izgledom između aktivnih i neaktivnih studentica. Pretpostavlja se da će studentice koje se nalaze u stadiju održavanja bitizadovoljnije tjelesnim izgledom u usporedbi sa studenticama koje se nalaze u ostalim stadijima promjene ponašanja povezanih s vježbanjem te da će tjelesno aktivne studentice imati pozitivniju percepciju svog tjelesnog izgleda.

\section{Mjerni instrumenti i varijable}

Skala za mjerenje procesa promjene (URICA; University of Rhode Island Change Assessment Scale, McConnaughy i sur., 1989), utemeljena na transteorijskom modelu spremnosti na promjenu ponašanja povezanih $\mathrm{s}$ vježbanjem. $\mathrm{Na}$ početku upitnika redovita tjelovježba je definirana kao bilo koja planirana tjelesna aktivnost (npr. brzo hodanje, aerobika, trčanje, vožnja bicikla, plivanje, veslanje itd.) koja se provodi 3 do 5 puta tjedno u trajanju 20 - 60 minuta po treningu. $\mathrm{Na}$ osnovu te definicije sudionici se klasificiraju u jedan od sljedećih stadija: predkontemplacija - neaktivni, bez namjere započinjanja s tjelovježbom u idućih 6 mjeseci; kontemplacija - neaktivni, s namjerom da započnu s tjelovježbom unutar idućih 6 mjeseci; priprema - neaktivni, s namjerom da počnu s tjelovježbom u idućih 30 dana; akcija aktivni, redovito vježbaju manje od 6 mjeseci; održavanje - aktivni, sudjeluju u redovnoj tjelovježbi duže od 6 mjeseci. 
Skala percepcije tjelesnog izgleda slikovnim podražajima (Figure Rating Scale, FRS, Stunkard i sur., 1983), sačinjena je od devet ilustracija ženskog tijela poredanih po: od najvitkije do najkrupnije siluete označenih brojevima od 1 do 9. Zadatak sudionica je napraviti dvije procjene: odabrati figuru za koju smatraju da najbolje reprezentira njihov aktualan izgled te onu koja prikazuje njihov željeni izgled na skali procjene od 1 do 9 . Numerička razlika između procjene sadašnjeg i željenoga izgleda predstavlja razinu zadovoljstva/nezadovoljstva vlastitim tjelesnim izgledom. Teorijski raspon rezultata kreće se od -8 do +8 . Rezultat nula (0) označava da je osoba zadovoljna trenutnim vlastitim tjelesnim izgledom. Ako je apsolutna razlika veća, smatra se da je osoba manje zadovoljna vlastitim tijelom dok predznak upućuje na smjer nezadovoljstva (predznak minus označava da osoba želi povećati, a predznak plus da želi smanjiti tjelesnu masu). Za provjeru konstruktne valjanosti rabljenog slikovnog materijala izračunata je korelacija procjene aktualnog tjelesnog izgleda s indeksom tjelesne mase i ona je iznosila $r s=0,79$.

Anketni upitnik koji je sadržavao pitanja o dobi i samoprocjeni tjelesne mase i tjelesne visine. $\mathrm{Na}$ temelju tjelesne mase i visine izračunat je indeks tjelesne mase ili Quetletov indeks (ITM). ITM se računa kao omjer tjelesne mase i kvadrata tjelesne visine. Tjelesna masa izražava se $u$ kilogramima, a tjelesna visina u metrima. Dobiveni rezultat pokazuje je li osoba pothranjena $(<18,5)$, primjereno uhranjena $(18,5-24,9)$, pretjerano uhranjena $(25,0-29.9)$ ili je pretila $(>30,0)(\mathrm{WHO}, 2018)$.

\subsection{Sudionici}

Uzorak sudionica čini 87 studentica Rudarsko-geološko-naftnog fakulteta Sveučilišta u

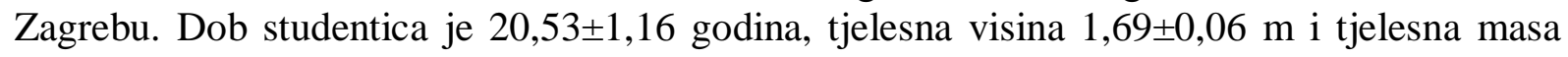
$60,97 \pm 8,63 \mathrm{~kg}$.

\subsection{Način prikupljanja podataka}

Prikupljanje podataka je organizirano putem online sustava za istraživanje: Google forms. U istraživanju nisu prikupljane IP adrese pa je anonimnost bila zagarantirana što je napomenuto i u uvodu same ankete. Istraživanje je provedeno tijekom travnja 2021. godine.

\subsection{Metode obrade podataka}

Obrada podataka je provedena kompjutorskim statističkim programom Statistika 13.5.0.17.Za sve varijable izračunati su osnovni deskriptivni pokazatelji. Izračunate su i frekvencije i postotci pojedinih odgovora Normalitet distribucije varijabli testiran je Shapiro-Wilk W testom. Za provjeru konstruktne valjanosti korištenog slikovnog materijala u Skali percepcije slikovnim podražajima izračunat je Spearmanov koeficijent za provjeru povezanosti procjene aktualnog tjelesnog izgleda i ITM. Za utvrđivanje razlika u zadovoljstvu/nezadovoljstvu tjelesnim izgledom studentica po pojedinim stadijima transteorijskog modela korišten je Kruskal-Wallis test. Za ispitivanje značajnosti razlika između grupa aktivnih i neaktivnih studentica $u$ zadovoljstvu/nezadovoljstvu tjelesnim izgledom i ITM korišten je Mann-Whitney U test za nezavisne uzorke.

\section{Rezultati}


U istraživanju je sudjelovalo 87 studentica Rudarsko-geološko-naftnog fakulteta Sveučilišta u

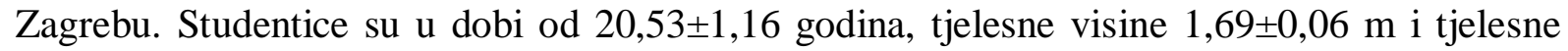
mase $60,97 \pm 8,63 \mathrm{~kg}$. Na temelju tjelesne mase i visine izračunat je ITM koji iznosi 21,26 $\pm 3,04$.

Prilikom procjene sadašnjeg izgleda najveći postotak studentica odabire figuru broj 4 (39,08\%) i figuru broj 3 (29,89\%), a nešto manje figuru broj 2 (17,24\%). Samo jedna studentica odabrala je za procjenu svog sadašnjeg izgleda figuru1 koja prikazuje ekstremnu mršavost. Ukupno 10,34\% studentica izabralo je figuru 5 dok je jedna studentica izabrala figuru 6 i jedna figuru 7. Niti jedna studentica nije odabrala za procjenu sadašnjeg izgleda figuru 8 ili 9.

U uzorku zagrebačkih studentica 41,38\% ih kod procjene željenog izgleda odabire figuru $3 \mathrm{kao}$ najpoželjniju a odmah nakon toga slijedi figura 4 (40,23\%). Figuru 2 odabralo je 14,94\% studentica dok je figuru 5 odabralo 2,3\% a 1,15\% odabrao je figuru 1. Niti jedna studentica za procjenu svoga željenog izgleda nije odabrala figure 6, 7, 8 i 9 (Tablica 1.).

Tablica 1. Frekvencije procjena sadašnjeg i željenog izgleda sudionica

\begin{tabular}{|c|c|c|}
\hline \multirow{2}{*}{ Figure } & Frekvencija (\%) & Frekvencija (\%) \\
\cline { 2 - 3 } & Sadašnji izgled & Željeni izgled \\
\hline 1 & $1(1,15)$ & $1(1,15)$ \\
\hline 2 & $15(17,24)$ & $13(14,94)$ \\
\hline 3 & $26(29,89)$ & $36(41,38)$ \\
\hline 4 & $34(39,08)$ & $35(40,23)$ \\
\hline 5 & $9(10,34)$ & $2(2,30)$ \\
\hline 6 & $1(1,15)$ & $0(0,00)$ \\
\hline 7 & $1(1,15)$ & $0(0,00)$ \\
\hline 8 & $0(0,00)$ & $0(0,00)$ \\
\hline 9 & $0(0,00)$ & $0(0,00)$ \\
\hline
\end{tabular}

Legenda:1-9 - figure na Stunkardovoj skali

Razina zadovoljstva/nezadovoljstva tjelesnim izgledom izračunata je kao razlika između procjene sadašnjeg i željenog izgleda a naziva se diskrepancija ili indeks odstupanja. Dobiveni rezultati pokazuju da je ukupno je 40,23\% studentica zadovoljno svojim tjelesnim izgledom, dok je 59,77\% studentica nezadovoljno tjelesnim izgledom. Njih 20,69\% želi povećati svoju tjelesnu masu dok ih 39,08\% želi smanjiti svoju tjelesnu masu. Od ukupnog broja studentica pet $(5,75 \%)$ ih želi smanjiti svoju tjelesnu masu za dvije siluete, a tri $(3,45 \%)$ studentice žele povećati svoju tjelesnu masu za dvije siluete (Tablica 2.).

Tablica 2. Frekvencije zadovoljstva/nezadovoljstva tjelesnim izgledom studentica

\begin{tabular}{|c|c|}
\hline $\begin{array}{c}\text { Zadovoljstvo/nezadovoljstvo } \\
\text { tjelesnim izgledom }\end{array}$ & $\begin{array}{c}\text { Frekvencija } \\
(\%)\end{array}$ \\
\hline-2 & $3(3,45)$ \\
\hline-1 & $15(17,24)$ \\
\hline 0 & $35(40,23)$ \\
\hline 1 & $29(33,33)$ \\
\hline 2 & $5(5,75)$ \\
\hline
\end{tabular}

Rezultati dobiveni skalom procesa promjene ponašanja vezanih uz vježbanje pokazuju da se najveći broj studentica nalazi u fazi akcije, njih 28 (32,18\%), dok je $26(29,89 \%)$ studentica koje su već prihvatile vježbanje kao svoju redovnu aktivnost te se nalaze u fazi održavanja. 15 
$(17,24 \%)$ studentica se izjasnilo da se nalazi u kontemplaciji a $18(20,69 \%)$ u fazi pripreme. Niti jedna studentica nije u fazi predkontemplacije.

Za utvrđivanje razlika u zadovoljstvu/nezadovoljstvu tjelesnim izgledom studentica po pojedinim stadijima transteorijskog modela korišten je Kruskal-Wallis test, $H(3)=2,44, p=0,49$. Studentice ovog uzorka ne razlikuju se u zadovoljstvu/nezadovoljstvu tjelesnim izgledom po pojedinim stadijima transteorijskog modela.

Kada se napravi podjela prema razini aktivnosti gdje se studentice dijele na neaktivne (predkontemplacija, kontemplacija i priprema) i aktivne (akcija i održavanje), a kriterij predstavlja početak redovitog vježbanja, tada su 33 studentice neaktivne $(37,93 \%)$ i 54 aktivne $(62,07 \%)$. Rezultati Mann-Whitney U testa za procjenu statističke značajnosti razlika rezultata između aktivnih i neaktivnih studentica $u$ varijabli zadovoljstva/nezadovoljstva tjelesnim izgledom ne upućuju na statistički značajne razlike između tih dviju grupa $(Z=0,40, p=0,69)$. Mann-Whitney $U$ testom ispitana je i razlika između dovoljno i nedovoljno aktivnih studentica u njihovom ITM $(Z=-0,15, p=0,88)$ (Tablica 3.).

Tablica 3. Razlike između aktivnih i neaktivnih studentica u zadovoljstvu/nezadovoljstvu tjelesnim izgledom i ITM

\begin{tabular}{|c|c|c|c|c|}
\hline \multirow{2}{*}{} & \multicolumn{2}{|c|}{ AS (SD) } & \multicolumn{2}{c|}{ Mann-Whitney U test } \\
\cline { 2 - 5 } & aktivne & neaktivne & $\mathrm{p}$ & $\mathrm{Z}$ \\
\hline $\begin{array}{c}\text { Zadovoljstvo/nezadovoljstvo } \\
\text { tjelesnim izgledom }\end{array}$ & $0,24(0,91)$ & $0,15(0,94)$ & 0,69 & 0,40 \\
\hline ITM & $0,24(0,91)$ & $0,15(0,94)$ & 0,88 & $-0,15$ \\
\hline
\end{tabular}

Legenda: AS - aritmetička sredina; SD - standardna devijacija; ITM - indeks tjelesne mase

\section{Rasprava}

Sadašnji izgled sudionice su procijenile na sljedeći način: figuru broj 4 bira 39,08\%, figuru broj 3 bira 29,89\%, figuru broj 2 bira 17,24\%, figuru broj 5 bira 10,34\% a figure 1, 6 i 7 bira 1,15\% studentica. Slični rezultati dobiveni su u istraživanjima hrvatskih studentica gdje najfrekventniji odabir za procjenu sadašnjeg izgleda ima figura 4, zatim figura 3 a nakon toga figura 5 (Alić, 2015; Cvenić, 2016; Leško i sur., 2018). U istraživanju na talijanskim studenticama najveći postotak ih za procjenu sadašnjeg izgleda odabire figuru $5(21,3 \%)$ i $4(20,7 \%)$ (Zaccagni i sur., 2014) što ukazuje da se talijanske studentice percipiraju debljima u odnosu na hrvatske studentice.

Prilikom procjene željenog izgleda sudionice su kao najpoželjniju figuru odabrale figuru broj 3 $(41,38 \%)$, nakon toga figuru broj 4 (40,23\%) te figuru broj 2 (14,94\%). Figuru 5 odabralo 2,3\% a figuru 1 odabrao je $1,15 \%$ sudionica. Primjetno je kako je ideal mršavosti prisutan među studenticama zagrebačkog sveučilišta. Slični rezultati dobiveni su i u istraživanjima Alić (2015), Zaccagni i sur., (2014) i Cvenić (2016). Nešto drugačiji rezultati dobiveni su u istraživanjima Bulik i sur. (2001) te Leško i sur. (2018). Sudionice oba istraživanja najčešće su za procjenu željenog izgleda odabirale figuru 3, potom figuru 2 te figuru 4. Sudionice navedenih istraživanja žele izgledati mršavije u usporedbi sa studenticama ovog istraživanja. U istim istraživanjima nitko za procjenu željenog izgleda nije odabrao figure 8 i 9 . Figura 7 nije bila odabrana u istraživanju Leško i sur. (2018) dok se studentice ovog istraživanja uz navedene figure nisu opredijelile ni za figuru 6. 
Rezultati diskrepancije pokazuju da je 40,23\% studentica zadovoljno svojim tjelesnim izgledom. Od 59,77\% studentica koje nisu zadovoljne svojim trenutnim izgledom njih 20,69\% izjasnilo se da želi povećati svoju tjelesnu masu od čega njih tri za dvije siluete, a 39,08\% studentica želi smanjiti svoju tjelesnu masu od čega njih pet za dvije siluete. Rezultati dosadašnjih istraživanja pokazuju da je tjelesnim izgledom zadovoljno 33,3\% - 39,74\% studentica, $8 \%$ - 20\% njih želi povećati svoju tjelesnu masu dok ih $34 \%$ - $64 \%$ želi smanjiti tjelesnu masu (Alić, 2015; Cvenić i Barić, 2014; Leško i sur., 2018; Pokrajac-Bulian i sur., 2005; Zaccagni i sur., 2014). Značajan udio studentica nezadovoljnih vlastitim tjelesnim izgledom može se objasniti kroz prizmu nametnutih društvenih standarda o idealima ljepote. Kod žena društvo izjednačava mršavost $s$ ljepotom i atraktivnošću što može pridonijeti većem nezadovoljstvu tjelesnim izgledom. Mogući uzroci ovakvih rezultata nalaze se u znatnim sociokulturalnim pritiscima prema kojima društvo, kultura u kojoj živimo i nametnuti nam standardi o idealnom izgledu ženskog tijela imaju snažan utjecaj na percepciju tijela.

Sudionice je prema skali za mjerenje procesa promjene ponašanja povezanih s vježbanjem moguće svrstati u sljedeće stadije: kontemplacija 17,24\%, priprema 20,69\%, akcija 32,18\% i održavanje $29,89 \%$. Nijedna sudionica nije u stadiju predkontemplacije. Ukoliko se rezultati dobiveni skalom procesa promjene ponašanja vezanih $\mathrm{s}$ vježbanjem usporede $\mathrm{s}$ drugim istraživanjima vide se velike razlike u raspodjeli po stadijima. Marshall i Biddle (2001) u svojoj su meta-analizi dobili su sljedeće rezultate: 3\% predkontemplacija, 7\% kontemplacija, 31\% priprema, 18\% akcija, 41\% održavanje. Cvenić i Barić (2016) u istraživanju osječkih studentica izvještavaju da je 10 studentica $(9,8 \%)$ odgovorilo da se nalaze u stadiju predkontemplacije, 23 (22,5\%) u kontemplaciji, 31 (30,4\%) u pripremi, 17 (16,7\%) u akciji i 21 (20,6\%) u održavanju. Makedonski studenti u istraživanju Elezim i sur. (2020) izjasnili su se prema pet kategorija transteorijskog modela na sljedeći način: $11,8 \%$ predkontemplacija, 43,5\% kontemplacija, $12,10 \%$ priprema, $17,60 \%$ akcija i $14,90 \%$ održavanje. Kruskal-Wallis testom ispitano je postoje li razlike u zadovoljstvu/nezadovoljstvu tjelesnim izgledom studentica prema pojedinim stadijima spremnosti promjene ponašanja povezanih s vježbanjem. Utvrđeno je da značajne razlike ne postoje $(\mathrm{H}(3)=2,44, \mathrm{p}=0,49)$. Vidljivo je kako se većina zagrebačkih studentica nalazi u fazama akcije i održavanja te da su tjelesno aktivne. Podjela prema razini aktivnosti gdje se studentice dijele na neaktivne (predkontemplacija, kontemplacija i priprema) i aktivne (akcija i održavanje) upravo to i potvrđuje. 33 studentice (37,93\%) su neaktivne dok su $54(62,07 \%)$ aktivne. Ove podatke moguće je usporediti sa sličnim istraživanjima. Na sjevernoameričkim sveučilištima također je dobiven veći postotak studenata u stadijima akcija i održavanje: 75,4\% i 45,9 \% (Cardinal i sur., 2004; Wallace i Buckworth, 2001) kao i u istraživanju Cardinal i sur. (2003) gdje su evidentirali 66\% aktivnih studenata u stadijima akcija i održavanje na jednom finskom sveučilištu. U istraživanju turskih studenata postotak aktivnih iznosio je 28,1\%(Cengiz i sur., 2009). Keating i sur. (2005) proučavali su tjelesnu aktivnost 1843 kineska studenta kojih je $27,9 \%$ bilo uključeno u redovnu tjelesnu aktivnost dok su Wakui i sur. (2002) proučavali tjelesnu aktivnost studentica u Japanu i otkrili da 90,7\% studentica ne sudjeluje u tjelesnim aktivnostima a samo 9,4\% redovito sudjeluje u tjelesnim aktivnostima. Vidljivo je kako se rezultati posljednja tri istraživanja uvelike razlikuju od ovog istraživanja na zagrebačkim studenticama što je ohrabrujuće i daje naslutiti kako studentice ovog istraživanja, osim studentskim obvezana, vrijeme posvećuju i izvannastavnim aktivnostima među kojima je zasigurno i tjelesna aktivnost.

Ispitivanja provedena s ciljem utjecaja programa tjelovježbe na predodžbu o vlastitu tijelu dokazuju kako tjelesno aktivni pojedinci imaju bolju predodžbu o vlastitu tijelu uspoređujući ih s nedovoljno tjelesno aktivnima (Hausenblas and Fallon, 2006). Schwarz i sur. (2005) upućuju kako je nezadovoljstvo tjelesnim izgledom veće kod studentica nesportašica a razlike između više i manje tjelesno aktivnih dobili su i Duncan i sur. (2006). Uspoređujući nedovoljno 
tjelesno aktivne spram dovoljno aktivnih osoba rezultati u istraživanju Leško i sur. (2018) pokazuju statistički značajno veće zadovoljstvo tjelesnim izgledom u dovoljno tjelesno aktivnih osoba oba spola. Dovoljno i nedovoljno aktivne studentice u istraživanju Alić (2015) nisu se razlikovale u zadovoljstvu/nezadovoljstvu tjelesnim izgledom. Upravo takvi rezultati dobiveni su i u ovom istraživanju gdje se neaktivne i aktivne studentice također ne razlikuju u zadovoljstvu/nezadovoljstvu tjelesnim izgledom $(Z=0,40, p=0,69)$. Naime, aktivne i neaktivne studentice ovog istraživanja ne razlikuju se ni prema stupnju uhranjenosti koji je procijenjen prema veličini ITM $(Z=-0,15, p=0,88)$. S obzirom na to da je dokazana značajna povezanost ITM i nezadovoljstva tjelesnim izgledom (McArthur i sur., 2005; Sujoldžić i Lucia, 2007). Upravo bi to mogao biti razlog što se aktivne i neaktivne studentice ne razlikuju značajno $u$ zadovoljstvu/nezadovoljstvu tjelesnim izgledom. Istraživanja (Pokrajac-Bulian i sur., 2008; Sira i White, 2010; Van Vonderen i Kinnally, 2012) pokazuju kako je veća razina samopoštovanja povezana s većim zadovoljstvom tjelesnim izgledom te bi bilo za pretpostaviti, s obzirom na dobivene rezultate, kako i aktivne i neaktivne studentice ovog istraživanja imaju visoku razinu samopoštovanja a što bi bilo potrebno i ispitati.

Nedostatci ovog istraživanja proizlaze iz prigodnog i relativno malog uzorka sudionica te autoselekcije onih koji su pristali sudjelovati u istraživanju. Dodatni je nedostatak nepostojanje antropometrijskih mjera koje bi uz ITM pomogle procjeni građe tijela i bolje objasnile zadovoljstvo/nezadovoljstvo tjelesnim izgledom.

\section{Zaključak}

Usprkos poznatim dobrobitima tjelesnog vježbanja, tjelesna je neaktivnost globalni problem. Upravo dovoljna razina tjelesne aktivnosti, uz brojne zdravstvene, društvene, psihološke i ekonomske pozitivne učinke, utječe i na zadovoljstvo tjelesnim izgledom. Smanjenje tjelesne mase ili oblikovanje tijela utječu na povećano zadovoljstvo tijelom dok je moguće i da samo početak sudjelovanja u tjelesnim aktivnostima, bez vidljivih promjena u izgledu tijela, za posljedicu ima zadovoljstvo pojedinca.

U ovom radu istražena je razlika u zadovoljstvu tjelesnim izgledom kod studentica Rudarskogeološko-naftnog fakulteta u različitim stadijima promjene ponašanja povezanih s tjelesnim vježbanjem. Rezultati upućuju kako se studentice koje se nalaze u različitim stadijima spremnosti promjene ponašanja povezanih $\mathrm{s}$ vježbanjem ne razlikuju značajno $\mathrm{u}$ zadovoljstvu/nezadovoljstvu vlastitim tjelesnim izgledom. Također, provjerom razlika između dovoljno i nedovoljno tjelesno aktivnih studentica nisu utvrđene statistički značajne razlike $u$ zadovoljstvu/nezadovoljstvu tjelesnim izgledom niti u stupnju uhranjenosti.

Implementacija programa za promicanje zdravog načina života u obrazovni sustav uz obaveznu redovitu tjelesnu aktivnost te usmjeravanje pažnje na društvene vrijednosti koje favoriziraju razlike $\mathrm{i}$ individualne prednosti pomogli bi studenticama odmaknuti se od stereotipa i nametnutih vrijednosti. Svakako treba naglasiti da osjećaj vlastite vrijednosti uključuje sve čimbenike osobnosti, zajedno s estetskim, koji bi trebali predstavljati prednost, pridonoseći tako osjećaju emocionalnog zadovoljstva.

\section{Literatura}

1. Alić, J. (2015). 'Povezanost tjelesne aktivnosti studentica, samoprocjene zdravlja zadovoljstva tjelesnim izgledom', Disertacija, Sveučilište u Zagrebu, Kineziološki fakultet, citirano: 16.05.2021., https://urn.nsk.hr/urn:nbn:hr:117:082354 
2. Allender, S., Hutchinson, L. i Foster, C. (2008) 'Life-change events and participation in physical activity: A systematic review', Health Promotion International, str. 160-172. doi: 10.1093/heapro/dan012.

3. Baş, M. i Kiziltan, G. (2007) 'Relations among weight control behaviors and eating attitudes, social physique anxiety, and fruit and vegetable consumption in Turkish adolescents', Adolescence, 42, str. 167-178.

4. Bendixen, A. $i$ sur. (2007) 'The importance of physical activity for body satisfaction', Ugeskrift for Laeger, 169(46), str. 3966-3970.

5. Bulik, C. M. i sur. (2001) 'Relating body mass index to figural stimuli: Population-based normative data for Caucasians', International Journal of Obesity, 25(10), str. 1517-1524. doi: 10.1038/sj.ijo.0801742.

6. Bungić, M. i Barić, R. (2009) 'Tjelesno vježbanje i neki aspekti psihološkog zdravlja', Hrvatski športskomediciniski vjesnik, 24(2), str. 65-75.

7. Campbell, A. i Hausenblas, H. A. (2009) 'Effects of exercise interventions on body image: A meta-analysis', Journal of Health Psychology, 14(6), str. 780-793. doi: 10.1177/1359105309338977.

8. Cardinal, B. J., Tuominen, K. J. i Rintala, P. (2003) 'Psychometric assessment of Finnish versions of exercise-related measures of transtheoretical model constructs', International Journal of Behavioral Medicine, 10(1), str. 31-43. doi: 10.1207/S15327558IJBM1001_03.

9. Cardinal, B. J., Tuominen, K. J. i Rintala, P. (2004) 'Cross-cultural comparison of american and finnish college students' exercise behavior using transtheoretical model constructs',

Research Quarterly for Exercise and Sport, 75(1), str. 92-101. doi:

10.1080/02701367.2004.10609137.

10. Cengiz, C., İnce, M. L. i Çiçek, Ş. (2009) 'Exercise Stages of Change in Turkish University Students by Sex, Residence, and Department', Perceptual and Motor Skills, 108(2), str. 411421. doi: 10.2466/pms.108.2.411-421.

11. Cleaves, D. H. $i$ sur. (2000) 'Body image preferences of self and others: A comparison of spanish and american male and female college students', Eating Disorders, 8(4), str. 269-282. doi: 10.1080/10640260008251236.

12. Cvenić, J. (2016). 'Promjene zdravstvenog fitnesa studentica Sveučilišta u Osijeku pod utjecajem eksperimentalnog programa teorijske nastave tjelesne i zdravstvene kulture', Disertacija, Sveučilište u Zagrebu, Kineziološki fakultet, citirano: 16.05.2021., https://urn.nsk.hr/urn:nbn:hr:117:160508

13. Cvenić, J. i Barić, R. (2014) 'The construct validity of the figure rating scale based on estimates of female students on the university in Osijek', U Milanović, D. i Sporiš, G. (ur).7th International Scientific Conference on Kinesiology. Opatija, str. 698-702.

14. Cvenić, J. i Barić, R. (2016) 'Razlike u intrinzičnoj motivaciji studentica u različitim stadijima promjene ponašanja povezanih s vježbanjem', Hrvatski športskomedicinski vjesnik, 31(1), str. 22-28.

15. DiClemente, C. C. (1993) 'Changing Addictive Behaviors: A Process Perspective', Current Directions in Psychological Science, 2(4), str. 101-106. doi: 10.1111/1467-8721.ep10772571. 16. Duncan, M. J. i sur. (2006) 'Body dissatisfaction, body fat and physical activity in British children', International Journal of Pediatric Obesity, 1(2), str. 89-95. doi:

10.1080/17477160600569420.

17. Elezim, A. $i$ sur. (2020) 'Application of the Transtheoretical Model (TTM) to exercise behaviour among Macedonian college students', Journal of Human Sport and Exercise, 15(3), str. 706-717. doi: 10.14198/jhse.2020.153.19.

18. Furnham, A. i Calnan, A. (1998) 'Eating disturbance, self-esteem, reasons for exercising and body weight dissatisfaction in adolescent males', European Eating Disorders Review, 6(1), str. 58-72. doi: 10.1002/(SICI)1099-0968(199803)6:1<58::AID-ERV184>3.0.CO;2-V. 
19. Gyurcsik, N. C., Bray, S. R. i Brittain, D. R. (2004) 'Coping with barriers to vigorous physical activity during transition to university', Family and Community Health, 27(2). doi: 10.1097/00003727-200404000-00006.

20. Hausenblas, H. A. i Fallon, E. A. (2006) 'Exercise and body image: A meta-analysis', Psychology and Health, 21(1), str. 33-47. doi: 10.1080/14768320500105270.

21. Horga, S. i Barić, R. (2018) 'Utjecaj tjelesnog vježbanja na psihičku dobrobit', U MišigojDuraković, M. (ur).Tjelesno vježbanje i zdravlje. Zagreb: Znanje, str. 318-329.

22. Keating, X. D. $i$ sur. (2005) 'Cross-cultural validation of stages of exercise change scale among Chinese college students', European Physical Education Review, 11(1), str. 71-83. doi: $10.1177 / 1356336$ X05049825.

23. Kruger, J. $i$ sur. (2008) 'Body size satisfaction and physical activity levels among men and women', Obesity, 16(8), str. 1976-1979. doi: 10.1038/oby.2008.311.

24. Leško, L., Barić, R. i Ivanko, A. (2018) 'Tjelesna aktivnost i zadovoljstvo tjelesnim izgledom: Spolne razlike', Hrvatski športskomediciniski vjesnik, 33, str. 5-18.

25. Marshall, S. J. i Biddle, S. J. (2001) 'The transtheoretical model of behavior change: A meta-analysis of applications to physical activity and exercise', Annals of Behavioral Medicine, 23(4). doi: 10.1207/S15324796ABM2304_2.

26. McArthur, L. H. i Raedeke, T. D. (2009) 'Race and sex differences in college student physical activity correlates', American Journal of Health Behavior, 33(1), str. 80-90. doi: 10.5993/AJHB.33.1.8.

27. McArthur, L., Holbert, D. i Pena, M. (2005) 'An Exploration of the Attitudinal and Perceptual Dimensions of Body Image among Male and Female Adolescents from Six Latin American Cities', Adolescence, 40, str. 801-816.

28. McConnaughy, E. A. i sur. (1989) 'Stages of change in psychotherapy: A follow-up report', Psychotherapy, 26(4). doi: 10.1037/h0085468.

29. Nelson, T. F.i sur. (2007) 'Vigorous physical activity among college students in the United States.', Journal of physical activity \& health, 4(4). doi: 10.1123/jpah.4.4.496.

30. Pokrajac-Bulian, A. i sur. (2005) 'Nezadovoljstvo tjelesnim izgledom i navike hranjenja kod studentica i njihovih majki', Psihologijske Teme, 14(1), str. 57-70.

31. Pokrajac-Bulian, A., Ambrosi-Randić, N. i Kukić, M. (2008) 'Thin-Ideal Internalization and Comparison Process as Mediators of Social Influence and Psychological Functioning in the Development of Disturbed Eating Habits in Croatian College Females', Psychological Topics, 17(2), str. 221-245.

32. Pokrajac-Bulian, A. i Kandare, A. (1999) 'Povezanost općeg nezadovoljstva tjelesnim izgledom i nekih aspekata samopoimanja u studentskoj populaciji', Psihologijske teme, Psihologij(8), str. 63-79.

33. Prochaska, J. i Diclemente, C. (1983) 'Stages and Processes of Self-Change of Smoking Toward An Integrative Model of Change', Journal of consulting and clinical psychology, 51, str. 390-395. doi: 10.1037//0022-006X.51.3.390.

34. Schwarz, H. C. $i$ sur. (2005) 'Eating attitudes, body dissatisfaction, and perfectionism in female college athletes', North American Journal of Psychology, 7, str. 345-352.

35. Sira, N. i White, C. P. (2010) 'Individual and familial correlates of body satisfaction in male and female college students', Journal of American College Health, 58(6). doi: $10.1080 / 07448481003621742$.

36. Stunkard, A. J., Sørensen, T. i Schulsinger, F. (1983) 'Use of the Danish Adoption Register for the study of obesity and thinness.', Research publications - Association for Research in Nervous and Mental Disease, 60.

37. Sujoldžić, A. i Lucia, A. De (2007) 'A Cross-Cultural Study of Adolescents - BMI , Body Image and Psychological Well-Being', Collegium Antropologicum, 31(1), str. 123-130.

38. Van Vonderen, K. E. i Kinnally, W. (2012) 'Media effects on body image: Examining media 
exposure in the broader context of internal and other social factors', American Communication Journal, 14(2), str. 41-57.

39. Wakui, S. $i$ sur. (2002) 'Relation of the stages of change for exercise behaviors, selfefficacy, decisional-balance, and diet-related psycho-behavioral factors in young Japanese women', The Journal of sports medicine and physical fitness, 42, str. 224-232.

40. Wallace, L. S. i Buckworth, J. (2001) 'Application of the Transtheoretical Model to Exercise Behavior among Nontraditional College Students', American Journal of Health Education, 32(1), str. 39-47. doi: 10.1080/19325037.2001.10609396.

41. Wertheim, E. H., Mee, V. i Paxton, S. J. (1999) 'Relationships Among Adolescent Girls' Eating Behaviors and Their Parents' Weight-Related Attitudes and Behaviors', Sex Roles, 41(3), str. 169-187. doi: 10.1023/A:1018850111450.

42. Zaccagni, L. $i$ sur. (2014) 'Body image and weight perceptions in relation to actual measurements by means of a new index and level of physical activity in Italian university students', Journal of translational medicine, 12:42. doi: 10.1186/1479-5876-12-42. 